\title{
Hypertrophic Neuropathies and Malignant Peripheral Nerve Sheath Tumors in Transgenic Mice Overexpressing Glial Growth Factor $\beta 3$ in Myelinating Schwann Cells
}

\author{
Richard P. H. Huijbregts, ${ }^{1}$ Kevin A. Roth, ${ }^{1}$ Robert E. Schmidt, ${ }^{2}$ and Steven L. Carroll ${ }^{1}$ \\ ${ }^{1}$ Division of Neuropathology, Department of Pathology, The University of Alabama at Birmingham, Birmingham, Alabama 35294-0017, and ${ }^{2}$ Division of \\ Neuropathology, Department of Pathology, Washington University School of Medicine, St. Louis, Missouri 63110
}

\begin{abstract}
The neuregulin-1 (NRG-1) family of growth and differentiation factors exerts a variety of effects on Schwann cells and their precursors during nervous system development; however, NRG-1 effects on adult Schwann cells are poorly defined. Several lines of evidence suggest that NRG-1 actions on adult Schwann cells are distinct from those observed during development. To test this hypothesis, we generated transgenic mice overexpressing the NRG-1 isoform glial growth factor $\beta 3$ (GGF $\beta 3$ ) in myelinating Schwann cells [protein zero ( $\left.\mathrm{P}_{0}\right)$ $\mathrm{GGF} \beta 3$ mice]. $\mathrm{P}_{0}$-GGF $\beta 3$ mice develop resting tremors, gait abnormalities, decreased hindlimb strength, and paralysis by $\sim 7 \mathrm{months}$ of age. Sciatic nerves from these animals show a hypertrophic neuropathy characterized by demyelination, remyelination, and "onion bulb" formation. Development of this hypertrophic neuropathy is preceded by Schwann cell hyperplasia that is prominent in 1-month-old mice and present but decreased in 2- and 4-month-old animals. $\mathrm{P}_{0}$-GGF $\beta 3$ mice also develop peripheral ganglion-associated malignant peripheral nerve sheath tumors. Motor, sensory, and sympathetic ganglia from 1-, 2-, and 4-month-old $\mathrm{P}_{0}$-GGF $\beta 3$ mice uniformly contain intraganglionic, likely preneoplastic, Schwann cell proliferations. Examination of bromodeoxyuridine incorporation and caspase-3 activation in sciatic nerves and trigeminal ganglia indicates that Schwann cell hyperplasia in $\mathrm{P}_{0}$-GGF $\beta 3$ mice reflects increased proliferation rather than decreased apoptosis. These observations are consistent with the hypothesis that GGF $\beta 3$ induces proliferation of adult Schwann cells and demyelination of peripheral nerve axons. Furthermore, overexpression of this NRG-1 isoform frequently induces neoplastic Schwann cell proliferation within PNS ganglia, suggesting that NRG-1 may contribute to human Schwann cell neoplasia.
\end{abstract}

Key words: Schwann cell; erbB receptor; schwannoma; neuropathy; neuregulin; glial growth factor

\section{Introduction}

The phenotype of Schwann cells and their precursors is modulated during development by members of the neuregulin-1 (NRG-1) family of growth and differentiation factors. NRG-1 proteins, which include glial growth factor (GGF), neu differentiation factor, heregulin, and acetylcholine receptor-inducing activity, are alternatively spliced membrane-bound or soluble molecules derived from a single gene (Fischbach and Rosen, 1997). The soluble NRG-1 isoform GGF $\beta 3$ promotes glial differentiation of neural crest cells (Shah et al., 1994), the pluripotent precursors from which Schwann cells arise, and prevents these cells from differentiating into neurons. NRG-1 isoforms also regulate the survival, proliferation, and differentiation of Schwann cell precursors, the glial elements derived from neural crest cells (Dong et al., 1995), and prime these cells to express factors necessary for myelination. From late embryogenesis through the

Received Dec. 17, 2002; revised June 3, 2003; accepted June 6, 2003.

This work was supported by National Institutes of Health Grants R37 DK19645 (R.E.S.), R01 AG10299 (R.E.S.), and R01 NS37514 (S.L.C.). We thank Stephanie Byer, Lee Millican, Lucie Beaudet, and Cecelia Latham for expert technical assistance.

Correspondence should be addressed to Dr. Steven L. Carroll, Division of Neuropathology, Department of Pathology, The University of Alabama at Birmingham, 1720 Seventh Avenue South, SC843, Birmingham, AL 35294-0017. E-mail: carroll@path.uab.edu.

Copyright $\odot 2003$ Society for Neuroscience $\quad$ 0270-6474/03/237269-12\$15.00/0 neonatal period, axonally derived NRG-1 proteins "match" the number of Schwann cells and axons by promoting the proliferation, migration, and survival of axon-associated committed immature Schwann cells (Topilko et al., 1996; Felts, 1999; Adlkofer and Lai, 2000; Garratt et al., 2000a). It is thus apparent that NRG-1 is critically important throughout Schwann cell development, with the precise responses elicited by these factors depending on the developmental stage of the glia.

Although NRG-1 is also expressed by neurons projecting into the adult PNS (Chen et al., 1994; Bermingham-McDonogh et al., 1997), little is known regarding NRG-1 actions on adult Schwann cells. Several lines of evidence suggest that NRG-1 has in vivo effects on adult Schwann cells differing from those observed during development. Adult Schwann cells, unlike embryonic Schwann cells, depend on autocrine signals for survival (Cheng et al., 1998), having lost a requirement for axonally derived NRG-1 (Meyer et al., 1997; Morris et al., 1999; Wolpowitz et al., 2000); these observations are consistent with an absence of Schwann cell apoptosis in nerves from older rodents, both in the uninjured state and after nerve transection (Grinspan et al., 1996). Furthermore, GGF $\beta 3$ induces demyelination in established Schwann cell-neuron cocultures (Zanazzi et al., 2001); this contrasts with the observation that Schwann cell-targeted ablation of the NRG-1 receptor subunit erbB2 inhibits the initial myelination of 
axons during embryogenesis and early postnatal life (Garratt et al., 2000b). Additional clues to potential NRG-1 actions on adult Schwann cells are provided by studies in injured peripheral nerves, in which the expression of multiple NRG-1 isoforms has been found to be induced coincident with the onset of Schwann cell proliferation (Carroll et al., 1997). Tyrosine phosphorylation of Schwann cell erbB receptors is increased with a similar time course (Kwon et al., 1997), suggesting that NRG-1 promotes Schwann cell mitogenesis in the regenerating adult nerve. These observations argue that NRG-1 continues to regulate the phenotype of adult Schwann cells. NRG-1 actions on adult Schwann cells, however, likely differ from those encountered earlier in life. To test this hypothesis, we have generated transgenic mice that overexpress the NRG-1 isoform GGF $\beta 3$ in mature myelinating Schwann cells.

\section{Materials and Methods}

Animal care and surgical procedures. Mice were cared for in accordance with the guidelines of the NIH Guide for the Care and Use of Laboratory Animals. All animal experiments were approved by the Institutional Animal Care and Use Committee of the University of Alabama at Birmingham.

Mice were housed in standard cages with filter lids. Water and food were available ad libitum. Animals were killed by either decapitation or cardiac perfusion after being anesthetized with Metofane (ScheringPlough Research Institute, Union, NJ) or Nembutal (pentobarbital; Abbott Labs, North Chicago, IL).

Construction of a protein zero-GGF 33 transgene. A cDNA containing the entire coding sequence for GGF $\beta 3$ was constructed from three distinct clones, an approach that allowed a codon encoding a proline in our partial GGF $\beta 3$ cDNA (GenBank accession number AF194996; S. L. Carroll et al., unpublished data) to be replaced with sequences encoding the leucine more commonly present at this position. As the first step in this process, an SphI-EcoRV fragment from the 3' end of a GGF $\beta 1$ a cDNA (pSLC132; GenBank accession number AF194993) was replaced with an SphI-EcoRI-Klenow fragment from the $3^{\prime}$ end of the GGF $\beta 3$ clone pSLC343. The N-terminal sequence of the GGF $\beta 3$ cDNA was then reassembled by replacing a BamHI-NotI fragment in this intermediate construct with a BamHI-NotI fragment from a genomic clone (pSLC384) containing sequences encoding the entire kringle domain. The complete GGF $\beta 3$ cDNA sequence was cloned into vector pGEM-11f (+) (Promega, Madison, WI) to produce pSLC405. The complete cDNA was then released from pSLC405 by digestion with BamHI and HindIII. The protruding ends of the GGF $\beta 3$ cDNA were blunted using DNA polymerase I (Klenow fragment), and the cDNA was ligated to AscI linkers (New England Biolabs, Beverly, MA). Subsequently, the GGF $\beta 3$ cDNA was subcloned into pBluescript II KS (+) cut with EcoRV to produce pSLC409. The GGF 33 cDNA was released from pSLC409 by partial digestion with $A s c \mathrm{I}$ and then cloned into $A s c \mathrm{I}$-digested mouse protein zeroTOTA ( $\mathrm{mP}_{0}$ TOTA; Feltri et al., 1999) to produce the transgene construct pSLC410. The linearized fragment used to generate transgenic animals was released by digesting pSLC410 with PacI and SpeI, which liberates the $\mathrm{P}_{0}$ sequence containing the inserted GGF $\beta 3$ cDNA from the vector backbone.

Generation of transgenic mice. To generate transgenic animals, the linearized transgene construct was injected into fertilized C57BL/6 $\times$ SJL hybrid $\mathrm{F}_{1}$ oocytes, which were reimplanted into pseudopregnant Swiss Webster recipients. The resulting offspring were screened using PCR with genomic DNA isolated from tail preps. The primers used for these screens were a forward primer (5'-ATCCACATCAACATCCACG-3') corresponding to nucleotides 1115-1133 (relative to the initiation ATG) of the GGF 33 sequence and a reverse primer $\left(5^{\prime}\right.$ AAGTTGCTGAGAGACCAC-3') corresponding to nucleotides 123-106 relative to the initiation ATG in exon 1 of the murine major myelin $\mathrm{P}_{0}$ sequence. Transgenic founders and their offspring were backcrossed to $\mathrm{C} 57 \mathrm{BL} / 6 \mathrm{~J} \times \mathrm{SJL} / \mathrm{J} \mathrm{F}_{1}$ hybrids (The Jackson Laboratory, Bar Harbor, ME).

Semiquantitative reverse transcription-PCR. Total RNA was isolated from tissue or cultured cells with Trizol (Invitrogen, San Diego, CA). After DNase treatment (Promega), RNA was reverse transcribed with Superscript II reverse transcriptase (Invitrogen). A portion of the DNasetreated sample was not reverse-transcribed and was used to verify an absence of genomic DNA contamination. These cDNAs served as templates for semiquantitative reverse transcription (RT)-PCR. Primers for detection of transgene transcripts were designed using Primer Express II software (Applied Biosystems, Foster City, CA). The GGF $\beta 3$ forward primer ( $5^{\prime}$-CCTCTGCCAACATCACCATTG-3') corresponds to nucleotides 1164-1174 of the GGF $\beta 3$ rat cDNA sequence (GenBank accession number AF194996). The GGF $\beta 3$ reverse primer (5'-TGACGGGTTTGACAGGTCCT-3') corresponds to nucleotides $1414-1393$ of the GGF $\beta 3$ rat cDNA sequence. To facilitate normalization of GGF $\beta 3$ mRNA levels, cyclophilin mRNA levels were also assayed. The cyclophilin forward primer (5'-CAAGACTAGGTGGCTGGATGG-3') corresponds to nucleotides 393-413 in the rat cyclophilin cDNA sequence (Danielson et al., 1988). The cyclophilin reverse primer (5'TAAAATGCCCGCAAGTCAAAGAAA-3') corresponds to nucleotides 561-538 in the rat cyclophilin cDNA sequence. PCR was performed using a PerkinElmer Life Sciences (Emeryville, CA) GeneAmp 2400 thermocycler. PCR conditions and empirical determination of the linear range of the PCR reaction for each primer pair were established as described (Carroll and Frohnert, 1998) using cDNA isolated from JS1 cells transiently transfected with plasmid pSLC458, which contains the GGF $\beta 3$ construct under the control of the cytomegalovirus immediate early promoter. Cycle parameters, after an initial 3 min melt at $94^{\circ} \mathrm{C}$, were $30 \mathrm{sec}$ at $94^{\circ} \mathrm{C}$ followed by $30 \mathrm{sec}$ at $60^{\circ} \mathrm{C}$ and $1 \mathrm{~min}$ at $72^{\circ} \mathrm{C}$. The midpoints of the logarithmic range of amplification were determined to be 27 cycles for GGF $\beta 3$ and 28 cycles for cyclophilin; consequently, amplification for assays of GGF $\beta 3$ and cyclophilin mRNA levels in sciatic nerves was performed using 27 and 28 cycles, respectively.

Western blot analyses. Protein from the sciatic nerve was isolated using Trizol (Invitrogen) according to the manufacturer's protocol. The denatured protein pellet was resuspended in $100 \mathrm{~mm}$ Tris- $\mathrm{HCl}, \mathrm{pH} 6.8$, and $1 \% \mathrm{SDS}$, heated at $55^{\circ} \mathrm{C}$ and sonicated twice $(30 \mathrm{sec} /$ sonication with a 1 min cooling interval between sonications) in a bath sonicator. Samples were centrifuged at $20,000 \times g$ for $5 \mathrm{~min}$. The supernatant was removed and assayed for protein content. Twenty micrograms of protein were resolved by SDS-PAGE, immunoblotted onto a polyvinylidene difluoride membrane, and probed with a rabbit polyclonal pan-neuregulin antibody (Carroll et al., 1997) followed by a horseradish peroxidaseconjugated donkey anti-rabbit secondary antibody (Jackson ImmunoResearch, West Grove, PA). Immunoreactive species were detected by chemiluminescence (SuperSignal Pico chemiluminescence kit; Pierce, Rockford, IL).

Preparation of plastic sections for light and electron microscopic analyses. Tissues were immersion-fixed in 3\% glutaraldehyde in Sorensen's buffer for $1-2 \mathrm{hr}$ at room temperature and then postfixed in this same fixative overnight at $4^{\circ} \mathrm{C}$. Sciatic nerve segments and ganglia were then postfixed in $\mathrm{OsO}_{4}$, dehydrated through graded alcohols, and embedded in EponAraldite or Spurr's medium. Semithin sections of nerves cut perpendicular to the orientation of the axonal fibers were stained with toluidine blue for light microscopic examination. For electron microscopy, thinlayer sections were stained with uranyl acetate and lead citrate. Electron microscopy was performed using a Philips 200 electron microscope.

Bromodeoxyuridine incorporation studies. Mice were injected intraperitoneally with bromodeoxyuridine (BrdU) and 5-fluorouracil (5-FU; 60 $\mathrm{mg} / \mathrm{kg} \mathrm{BrdU}$ and $6 \mathrm{mg} / \mathrm{kg} 5-\mathrm{FU}$ ) for $90 \mathrm{~min}$ before killing. BrdU-pulsed animals were perfused transcardially with $4 \%$ paraformaldehyde in PBS and then postfixed in $4 \%$ paraformaldehyde at $4{ }^{\circ} \mathrm{C}$. The sciatic nerve, trigeminal nerve, selected PNS ganglia, jejunum (a positive control for BrdU incorporation), and, when applicable, tumor tissue were isolated.

Tissues were embedded in paraffin, and 5-6 $\mu \mathrm{m}$ sections were prepared and mounted on Superfrost Plus slides (Fisher Scientific, Pittsburgh, PA). Sections were deparaffinized in Citrisolve (Fisher Scientific) and rehydrated through isopropanol to water and then PBS. Citrate antigen retrieval was performed by steaming slides for $20 \mathrm{~min}$ in a rice steamer and then allowing slides to cool to room temperature for $20 \mathrm{~min}$. Endogenous peroxidase activity was blocked by treating slides with $3 \%$ 
$\mathrm{H}_{2} \mathrm{O}_{2}$ for $5 \mathrm{~min}$, followed by washes performed first with water and then with PBS. Sections were incubated for $15-30 \mathrm{~min}$ in tyramide signal amplification blocking buffer (PerkinElmer Life Sciences). After blocking, slides were incubated with goat-anti-BrdU antiserum (1:200,000 dilution in blocking buffer; antiserum kindly provided by Dr. Steven Cohn, Washington University School of Medicine) overnight at $4^{\circ} \mathrm{C}$. After three rinses in PBS, sections were incubated at room temperature for $1 \mathrm{hr}$ in blocking buffer containing donkey anti-goat-HRP (1:1000 dilution; Jackson ImmunoResearch). After three washes in PBS, sections were incubated with cyanine 3-tyramide in Plus Amp buffer (PerkinElmer Life Sciences) for $30 \mathrm{~min}$. Sections were then washed two times with PBS ( $5 \mathrm{~min} /$ wash), followed by a wash with PBS containing $0.04 \mu \mathrm{g} / \mathrm{ml}$ bisbenzamide to label nuclei within the sections. Sections were then washed twice more with PBS and mounted in PBS/glycerol, $(1: 1 \mathrm{v} / \mathrm{v})$

Digital images from immunostained preparations were acquired using a Zeiss (Thornwood, NY) Axioskop fluorescence microscope and analyzed using Image-Pro Plus acquisition and analysis software. Nuclei within the endoneurium (excluding those within the endoneurial vasculature) were identified as Schwann cells on the basis of the morphology of their nuclei (oval, blunt-ended nuclei oriented longitudinally relative to the long axis of the nerve); we and others have previously found these criteria to be quite reliable for the identification of Schwann cells in histologic sections (Asbury, 1967; Carroll et al., 1997). Schwann cells actively synthesizing DNA were identified by the presence of BrdU immunoreactivity colocalizing with bisbenzamide staining.

Immunohistochemistry for activated caspase-3, S100 $\beta$, and collagen type $I V$. These immunostains were performed on paraffin sections of nerves. Activated caspase- 3 was detected using a rabbit polyclonal antibody specific for this antigen (Cell Signaling, Inc.) with tyramide signal amplification immunohistochemistry performed as described above. $S 100 \beta \mathrm{im}-$ munoreactivity was detected using a rabbit polyclonal anti-S100 $\beta$ primary antibody (Dako, Carpinteria, CA; 1:200 dilution) and a Cy3conjugated anti-rabbit secondary antibody (Jackson ImmunoResearch). Immunostaining for collagen type IV was performed using a mouse monoclonal primary antibody specific for this antigen (clone PHM-12, $1.5 \mu \mathrm{g} / \mathrm{ml}$; Ventana Medical Systems, Tucson, AZ) followed by a horseradish peroxidase-conjugated secondary antibody, with immunoreactivity detected by diaminobenzidine deposition.

\section{Results}

\section{Generation of transgenic mice overexpressing the NRG-1 isoform GGF $\beta 3$ in myelinating Schwann cells}

To test the hypothesis that NRG-1 is capable of inducing Schwann cell dedifferentiation, proliferation, or both in the noninjured peripheral nerve, we produced transgenic mice constitutively overexpressing NRG-1 in this tissue. We chose to overexpress GGF $\beta 3$, an NRG-1 splice variant that is directly secreted without the need for release by a transmembrane domainspecific protease, in the peripheral nerve. The transgene for these experiments (referred to subsequently as the $\mathrm{P}_{0}$-GGF $\beta 3$ transgene) was constructed by inserting sequences encoding GGF $\beta 3$ into a genomic clone of the major peripheral myelin $\mathrm{P}_{0}$ gene, which has been modified so that the CDNA can be inserted at the $\mathrm{P}_{0}$ initiation codon (Fig. 1A). This vector has been found to reliably produce high-level expression in myelinating Schwann cells, with low-level expression first detectable at postnatal day 5 (P5) and high-level expression evident by $\mathrm{P} 15$ and persisting into adulthood (Feltri et al., 1999).

Four $\mathrm{P}_{0}$-GGF $\beta 3$ founders (founders 33-35 and 44) were identified and showed little evidence of neurologic or other abnormalities until they were $\sim 7$ months of age (see below). However, two of these founders produced no transgenic progeny, whereas a third produced only a single transgenic pup, which could not be further propagated (Table 1). Transgenic offspring were readily obtained from the fourth founder (founder 33). To assess trans-
$\mathbf{A}$
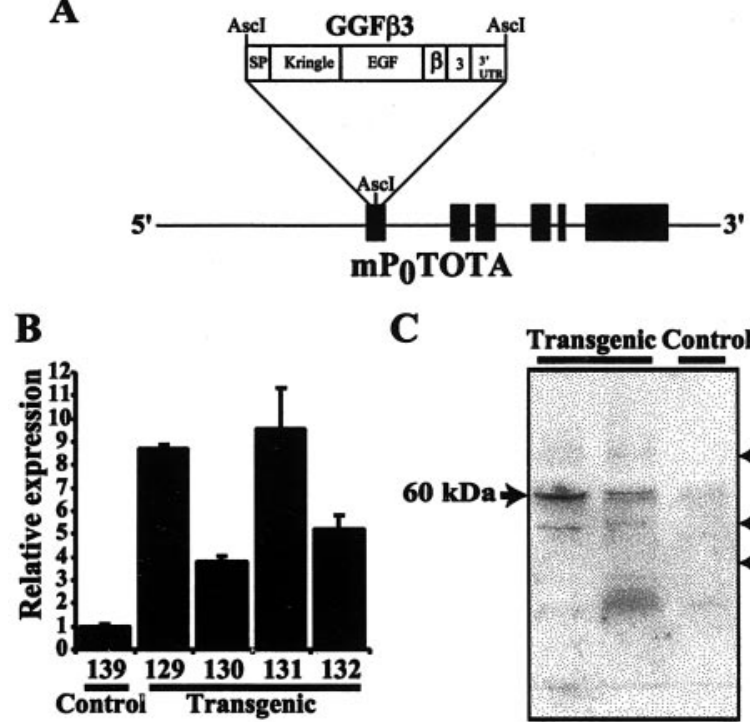

C

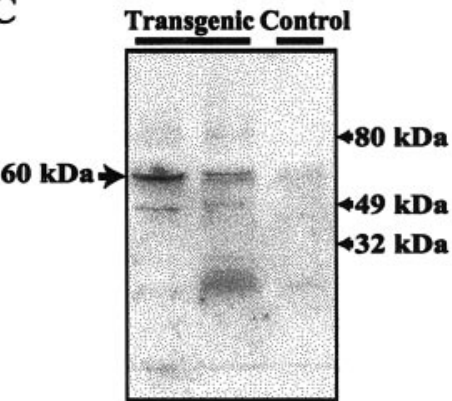

Figure 1. Mice carrying the $\mathrm{P}_{0}$-GGF $\beta 3$ transgene overexpress GGF $\beta 3$ in sciatic nerve. $A$, Schematic representation of the $\mathrm{P}_{0}-\mathrm{GGF} \beta 3$ transgene in which the expression of a rat GGF $\beta 3$ CDNA is directed by $6.0 \mathrm{~kb}$ of $5^{\prime}$ flanking sequence and intragenic regulatory elements from the mouse myelin $\mathrm{P}_{0}$ locus contained in $\mathrm{mP}_{0}$ TOTA (Feltri et al., 1999). Black boxes indicate exons of the $P_{0}$ gene, with the structural domains of the GGF $\beta 3$ CDNA indicated as white boxes. The GGF domains are as follows: SP, signal peptide; Kringle, kringle domain; EGF, EGF-like domain; $\beta$, EGF $\beta$-variant domain; 3, 3 variant juxtamembrane domain; and 3'-UTR, the GGF $\beta 3$ 3' untranslated region. The $\mathrm{P}_{0}$ start codon in $\mathrm{MP}_{0}$ TOTA has been replaced with an Ascl site, and the GGF $\beta 3$ CDNA has been inserted into this site. $B$, Semiquantitative RT-PCR analyses of RNA isolated from the sciatic nerves of $\mathrm{P}_{0}$-GGF $\beta 3$ mice (line 33) demonstrate that GGF $\beta 3$ mRNA is overexpressed in this tissue. Semiquantitative RT-PCR was performed using primers specific for GGF $\beta 3$ and the housekeeping gene cyclophilin with RNA isolated from the sciatic nerves of 4-month-old transgenic mice (Transgenic) or age-matched, nontransgenic controls (Control). Signals for GGF $\beta 3$ were normalized to cyclophilin levels in the same specimen. GGF $\beta 3 /$ cyclophilin ratios are presented as bars, with SEM indicated for each bar. The GGF $\beta 3$ /cyclophilin ratio from a nontransgenic mouse (139) is arbitrarily defined as 1, with the level of expression in individual mice normalized to this reference. Numbers under each bar are the identifiers of specific animals. C, Immunoblot analyses of protein from the sciatic nerves of $\mathrm{P}_{0}-\mathrm{GGF} \beta 3$ mice demonstrate that this tissue contains elevated levels of neuregulin-1 protein. Twenty micrograms of sciatic nerve protein from 2-month-old transgenic mice and nontransgenic littermates (line 33) were resolved, blotted, and probed with an antibody specific for the NRG-1 EGF-like common domain [a pan-neuregulin antibody (Carroll et al., 1997)]. The arrow to the left indicates the position of a $60 \mathrm{kDa}$ antigen that is expressed at increased levels in two different transgenic mice (Transgenic) relative to a nontransgenic control (Control). Arrows to the right indicate the positions of size markers.

\section{Table 1. Transgenic lines}

\begin{tabular}{lll}
\hline Founders $^{a}$ & Total offspring $^{b}$ & Transgenic offspring \\
\hline M33 & 42 & 18 \\
M34 & 63 & 1 \\
M35 & 0 & 0 \\
F44 & 30 & 1
\end{tabular}

${ }^{a}$ Founders are identified as male (M) or female (F) followed by their line number.

${ }^{b}$ Included are pups that died before ready to be tail-prepped and characterized.

gene expression in the progeny of $\mathrm{P}_{0}$-GGF $\beta 3$ founder 33, semiquantitative RT-PCR analyses were performed on RNA isolated from the sciatic nerves of 4-month-old transgenic animals and their nontransgenic littermates. GGF mRNA levels in the sciatic nerves of nontransgenic mice were barely detectable, with levels at the extreme lower end of our assay range (Fig. $1 B$ ). In contrast, GGF mRNA levels in line $33 \mathrm{P}_{0}$-GGF $\beta 3$ mice were much higher than in their nontransgenic littermates. Because of the very low levels of GGF mRNA in the nontransgenic sciatic nerve, we can 
only estimate that GGF mRNA levels in the sciatic nerves of 4-month-old $\mathrm{P}_{0}$-GGF $\beta 3$ animals are at least 4 - to 10 -fold higher than in age-matched nontransgenic controls. When probed with an antibody specific for the epidermal growth factor (EGF)-like common domain present in all NRG-1 isoforms (Carroll et al., 1997), sciatic nerve lysates from $\mathrm{P}_{0}$-GGF $\beta 3$ mice of line 33 were found to contain increased levels of a $60 \mathrm{kDa}$ NRG-1-like antigen (Fig. $1 C)$. The size of this NRG-1-like antigen is very similar to that previously reported for GGF-II ( 59 kDa; Goodearl et al., 1993; Marchionni et al., 1993), indicating that full-length GGF $\beta 3$ protein is overexpressed in sciatic nerves from these transgenic animals. Levels of expression of GGF $\beta 3$ mRNA and protein showed some variation between individuals of line 33; because GGF $\beta 3$ expression in these animals is directed by the regulatory elements of the $\mathrm{P}_{0}$ gene, and GGF $\beta 3$ has been found to repress $\mathrm{P}_{0}$ expression (Cheng and Mudge, 1996), variable GGF expression in $\mathrm{P}_{0}$-GGF $\beta 3$ mice may reflect cyclic induction and repression of transgene expression.

\section{Mice overexpressing GGF $\beta 3$ in myelinating Schwann cells develop hindlimb paralysis associated with hypertrophic neuropathy}

At $\sim 7$ months of age, founders 33-35 developed gait abnormalities and started dragging their hind legs. When picked up by their tails, these founders clasped their feet tightly to their bellies rather than demonstrating a normal outstretching of the hind legs and splaying of the toes. Hindlimb muscular strength was diminished, as demonstrated by a decreased ability to grasp with their hind feet. As their condition progressed, founders 33-35 developed ptosis, a hunched posture, and a prominent resting tremor. In addition, founder 34 demonstrated severe priapism toward the end of his course. In founder 44, hind leg weakness was the most prominent symptom, which eventually developed into complete hindlimb paralysis (Fig. 2A). No abnormalities of urination or defecation were present in any founder, indicating that spinal cord function was grossly intact. We subsequently observed similar neurologic abnormalities in the progeny of founder 33.

To investigate the anatomic basis of the neurologic abnormalities in these animals, necropsy examinations were performed on founders 44 and 35 and some of the progeny of founder 33 . No gross abnormalities were identified in these studies with the exception of atrophy of the hindlimb musculature. One micrometer plastic semithin cross sections of the sciatic nerves were prepared, stained with toluidine blue, and examined by light microscopy. Sciatic nerves from founders 35 (Fig. 2 B) and 44 (Fig. 2C) as well as mice from line 33 (see below) showed multiple abnormalities characteristic of a severe hypertrophic neuropathy including numerous well developed "onion bulbs" (e.g., see Fig. $2 B$, arrowhead). Most of the remaining large axons were thinly myelinated (Fig. $2 B$, arrows), and occasional structures morphologically consistent with actively degenerating axons were present (Fig. 2C, arrowheads). None of these changes were ever observed in sciatic nerves from age-matched nontransgenic controls (Fig. 2D).

Electron microscopic examination of nerves from founders 35
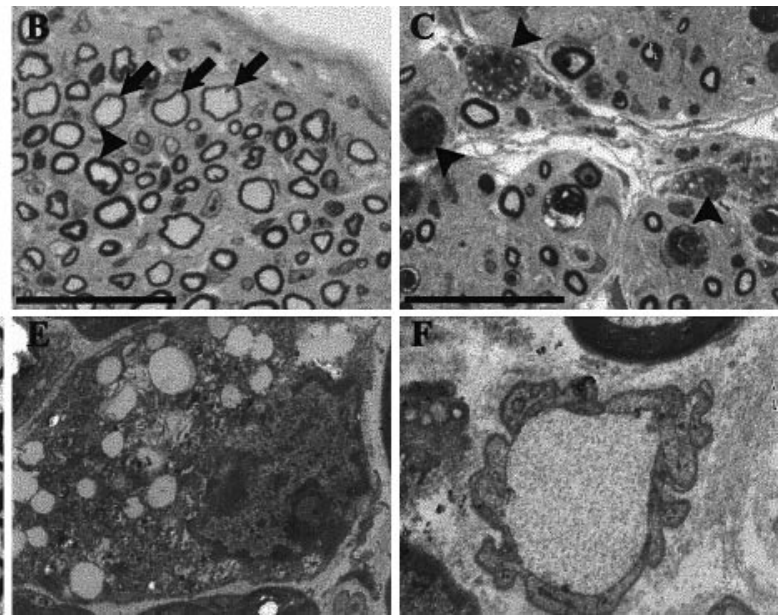

igure 2. Gait abnormalities and hindlimb paralysis are caused by a hypertrophic neuropathy in $\mathrm{P}_{0}-\mathrm{GGF} \beta 3$ founders 44 and 35 .

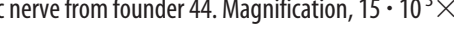

and 44 confirmed the presence of well developed onion bulbs. Furthermore, these studies demonstrated the presence of endoneurial lipid-laden macrophages (Fig. 2E) and occasional $(<0.1 \%)$ large unmyelinated ("naked") axons (Fig. 2 F). Sciatic nerves from $\mathrm{P}_{0}$-GGF $\beta 3$ transgenic mice therefore showed evidence of both demyelination (lipid-laden macrophages and naked axons) and remyelination (thinly myelinated large axons). As the same hypertrophic neuropathy occurs in founders 44 and 35 and animals from line 33, we conclude that this neuropathy results from GGF $\beta 3$ overexpression rather than line-specific integration site effects.

\section{The hypertrophic neuropathy in $\mathrm{P}_{0}$-GGF $\beta 3$ transgenic mice develops in adulthood}

The development of neurologic abnormalities at $\sim 7$ months of age suggests that the progression of clinical findings in $\mathrm{P}_{0}$-GGF $\beta 3$ transgenic mice is paralleled by the development of anatomic changes. To test this hypothesis, sciatic nerves were collected from $\mathrm{P}_{0}$-GGF $\beta 3$ transgenic (line 33) and wild-type control mice at 1 (seven transgenic and two wild-type), 2 (eight transgenic and two wild-type), 4 (four transgenic and one wild-type), and 7 (four transgenics and one wild-type) months of age. One micrometer plastic semithin cross sections were prepared from these tissues, stained with toluidine blue, and examined by light microscopy. At 1 month of age, there was no evidence of hypertrophic neuropathy in the sciatic nerves of $\mathrm{P}_{0}-\mathrm{GGF} \beta 3$ mice (Fig. $3 A$ ), with myelination in this tissue similar to that seen in age-matched controls (data not shown). By 2 months of age, however, rudimentary onion bulbs were detected in the sciatic nerves of some transgenic animals (Fig. 3B, arrows). By 4 months of age, both onion bulbs and many large, thinly myelinated axons were present, abnormalities that were even more evident in 7-monthold animals (Fig. 3C). Onion bulb formation in particular was very prominent in many 7 -month-old transgenic mice of line 33, much as was seen in founders 35 and 44 (see above). None of these pathologic findings were evident in the sciatic nerves of wild-type control animals. 


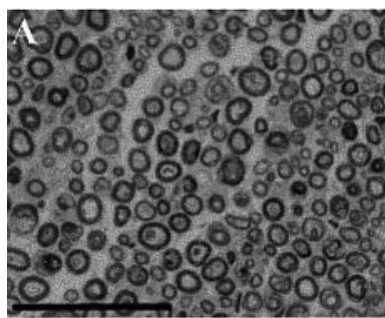

1 month

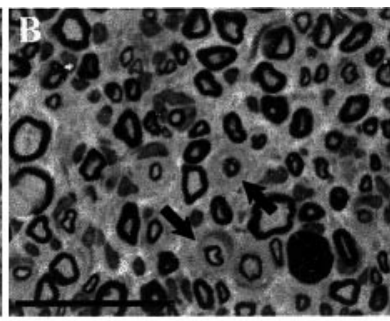

2 months

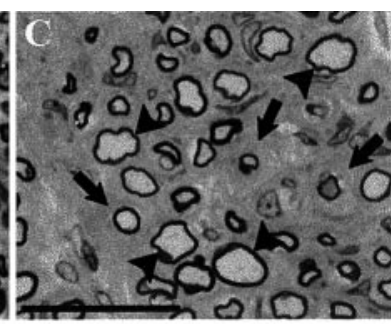

7 months
Figure 3. A hypertrophic neuropathy whose development is preceded by a period of Schwann cell hyperplasia occurs in mice overexpressing GGF $\beta 3$ in myelinating Schwann cells. Light photomicrographs of representative toluidine blue-stained plastic semithin cross sections of sciatic nerves from $\mathrm{P}_{0}-\mathrm{GGF} \beta 3$ mice at $1(A), 2(B)$, and $7(C)$ months of age are shown. Arrows in $B$ and Cindicate onion bulbs. Arrowheads in C indicate some of the thinly myelinated large axons.

Although the findings described above were commonly evident in the sciatic nerves of $\mathrm{P}_{0}$-GGF $\beta 3$ mice of line 33 , the time course with which these pathologic changes developed was variable in some animals, with dysfunction developing more slowly in some individuals and more rapidly in others. One exceptional mouse had already developed severe hindlimb paralysis by the age of 2.5 months.

\section{Schwann cell hyperplasia is evident in the sciatic nerve of $\mathrm{P}_{0^{-}}$} GGF $\beta 3$ transgenic mice by 1 month of age

Neuregulin-1 promotes the survival (Grinspan et al., 1996) and proliferation (Topilko et al., 1996; Felts, 1999; Adlkofer and Lai, 2000; Garratt et al., 2000a) of neonatal Schwann cells. If NRG-1 has either of these effects on adult Schwann cells, we would expect that Schwann cell hyperplasia would be evident in the nerves of $\mathrm{P}_{0}$-GGF $\beta 3$ mice. To test this hypothesis, longitudinal paraffin sections of sciatic nerves collected from the same $P_{0}-G G F \beta 3$ transgenic and age-matched control animals described above were stained with hematoxylin and eosin and examined by light microscopy. At all ages examined (1, 2, 4, and 7 months), the sciatic nerves of $\mathrm{P}_{0}$-GGF $\beta 3$ mice contained more Schwann cell nuclei per high-power field $\left(0.3 \mathrm{~mm}^{2}\right)$ than nerve from nontransgenic littermates (Fig. $4 A$ ). Interestingly, however, the density of Schwann cell nuclei also appeared to decrease with increasing age in both transgenic and control animals. To confirm these impressions, counts of the number of Schwann cell nuclei per 0.3 $\mathrm{mm}^{2}$ were performed on sections of sciatic nerves from 1-, 2-, 4-, and 7-month-old transgenic and nontransgenic mice. Nerves from 1-, 2-, and 4-month-old $\mathrm{P}_{0}$-GGF $\beta 3$-overexpressing mice contained significantly ( $p \leq 0.01)$ higher Schwann cells densities than age-matched nontransgenic littermates (Fig. $4 B$ ). Although highly variable, the number of Schwann cell nuclei per $0.3 \mathrm{~mm}^{2}$ was also increased in 7-month-old $\mathrm{P}_{0}$-GGF $\beta 3$ mice.

These counts also confirmed that the average density of Schwann cell nuclei decreased with age in $\mathrm{P}_{0}$-GGF $\beta 3$ animals. Sections of sciatic nerves from transgenic mice contained $\sim 400$ 550 nuclei $/ 0.3 \mathrm{~mm}^{2}$ at 1 month of age, $200-275$ nuclei $/ 0.3 \mathrm{~mm}^{2}$ at 2 months, $150-225$ nuclei/ $0.3 \mathrm{~mm}^{2}$ at 4 months, and $75-225$ nuclei $/ 0.3 \mathrm{~mm}^{2}$ at 7 months (Fig. $4 C$ ). An age-associated decrease in the average density of Schwann cell nuclei was also observed in sciatic nerves from control mice; this decrease was much more modest, however, than that observed in $\mathrm{P}_{0}$-GGF $\beta 3$ mice. Measurements of the cross-sectional area of sciatic nerves from 1-month-old (11 transgenic and 3 control), 2-month-old ( 12 transgenic and 4 control), and 4 -month-old ( 5 transgenic and 9 control) $\mathrm{P}_{0}$-GGF $\beta 3$ mice and nontransgenic littermates showed that the average nerve area increased with age, with the nerve area in 4-month-old animals being $\sim 150 \%$ of that observed in 1-month-old mice. At all three ages, however, there was no significant difference in the average crosssectional area of sciatic nerves from transgenic and nontransgenic mice [e.g., nerve area in 4-month-old transgenic mice, $216,814 \pm 35531 \mu \mathrm{m}^{2}$ (mean \pm SD of the mean); in 4-month-old nontransgenic mice, 197,226 $\left.\pm 32658 \mu \mathrm{m}^{2}\right]$. These observations suggest that at least one factor contributing to the age-related decrease in Schwann cell nuclear density in $\mathrm{P}_{0}$-GGF $\beta 3$ mice is the endoneurial accumulation of elements (e.g., the Schwann cell processes forming onion bulbs and endoneurial collagen) in the increasingly pathologic nerve, which produces a progressively wider separation of Schwann cell nuclei. A similar age-related decrease in Schwann cell nuclear density occurs in sciatic nerves from nontransgenic animals and probably reflects the endoneurial accumulation of myelin and other molecules associated with maturation of the nerve. Because the average cross-sectional area of sciatic nerves from 4-month-old transgenic and nontransgenic mice is not significantly different, it seems likely that the hypertrophy observed for individual Schwann cell-axon units in $\mathrm{P}_{0}$-GGF $\beta$ mice is offset by the loss of myelin and axons that occurs as the pathology progresses, resulting in a minimal overall change in nerve diameter.

To verify that the cells producing hyperplasia in nerves from $\mathrm{P}_{0}$-GGF $\beta 3$ mice are indeed Schwann cells, sciatic nerve sections from 1-month-old transgenic animals and nontransgenic littermates were stained for the Schwann cell marker S100 $\beta$ and collagen type IV, a protein component of the basal laminae; collagen type IV deposition is found around Schwann cells (Baron-Van Evercooren et al., 1986; Lorimier et al., 1992) and endothelial cells (Lorimier et al., 1992) but not around other cell types within the endoneurium. $\mathrm{S} 100 \beta$ immunoreactivity was associated with both the normal Schwann cells in nontransgenic nerves (data not shown) and the hyperplastic elements within nerves from $\mathrm{P}_{0^{-}}$ GGF $\beta 3$ mice (Fig. 5A). Collagen type IV immunoreactivity was evident as faint brown staining outlining Schwann cell-axon units and as stronger endothelial-associated staining in nerves from nontransgenic mice (Fig. $5 B$ ). In contrast, collagen type IV immunoreactivity was prominent in nerves from $\mathrm{P}_{0}$-GGF $\beta 3$ mice (Fig. 5C) and was frequently observed to invest the hyperplastic cells within this tissue (Fig. $5 C$, arrows). Because endothelial cells are not $S 100 \beta$-positive, the $S 100 \beta$ and collagen type IV immunoreactivity associated with hyperplastic elements in $\mathrm{P}_{0^{-}}$ GGF $\beta 3$ nerve identifies these cells as Schwann cells.

\section{Mice overexpressing GGF $\beta 3$ in myelinating Schwann cells develop malignant peripheral nerve sheath tumors} In addition to the neurologic abnormalities described above, founders 33 and 34 demonstrated decreasing responsiveness associated with bulging eyes that first became evident at 6-7 months of age. When autopsied, these mice were found to have large intracranial masses at the base of the skull. The masses were centered on the trigeminal ganglion and displaced the brain upward; both gross and microscopic examinations showed no evidence that these masses invaded the brain. Microscopic examination of the mass from founder 34 (Fig. 6A) showed this tumor to be a hypercellular neoplasm composed of Schwann cell-like spindled cells containing elongated nuclei. Mitoses and areas of 
tumor necrosis were common in this neoplasm. Although containing small areas histologically similar to the tumor from founder 34, the majority of the intracranial neoplasm from founder 33 was much more hypercellular and contained even more numerous mitotic figures (Fig. 6B). Ganglionic neurons were found entrapped within both neoplasms, confirming their association with the trigeminal ganglion.

Similar neoplasms were found in three of the older (6- to 10-month-old) progeny of $\mathrm{P}_{0}$-GGF $\beta 3$ founder 33. These neoplasms, like the tumor found in founder 33, were markedly hypercellular lesions containing numerous mitotic figures. Two of these tumors were associated with the trigeminal ganglion. The third neoplasm was within the sciatic nerve, producing diffuse enlargement of the nerve that began at the exit of the nerve roots from the vertebral canal and extended along the upper half of the nerve. No such neoplasms were ever observed in the nontransgenic littermates of these mice. Again, because neoplasms were found in founder 34 as well as several mice from line 33 , we conclude that the development of these tumors results from transgene-directed GGF $\beta 3$ overexpression rather than integration site effects.

The morphologic features of the tumors developing in $\mathrm{P}_{0}$-GGF $\beta 3$ mice are highly similar to those of human malignant peripheral nerve sheath tumors (MPNSTs), a type of neoplasm that may occur either sporadically or as part of the hereditary cancer predisposition syndrome neurofibromatosis type 1 (Gutmann et al., 1997; Parada, 2000; Gutmann, 2001). To confirm this impression, immunohistochemical studies and ultrastructural examination of the MPNST-like neoplasms occurring in $\mathrm{P}_{0}$-GGF $\beta 3$ mice were performed in accordance with recent consensus recommendations for the evaluation of neoplasms occurring in transgenic mice (Weiss et al., 2002). Extensive areas within the tumors were immunoreactive for the Schwann cell marker S100 $\beta$ (Fig. $6 C)$, indicating that these neoplasms, like human MPNSTs, were Schwann cell tumors. Furthermore, individual tumor cells were surrounded by immunoreactivity for collagen type IV, a basal lamina protein that demonstrates a similar distribution in human MPNSTs (Leong et al., 1997; Vang et al., 2000). Ultrastructural examination demonstrated that the tumor cells had broad, interdigitating processes (Fig. $6 E$ ) densely laden with ribosomes and endoplasmic reticulum. Tumor cells were frequently invested by a basal lamina that at times extended away from the cell surface as loops (Fig. $6 F$, arrowhead). Long-spacing collagen (Luse body) was also identified within the tumor. These ultrastructural features are highly similar to those of human
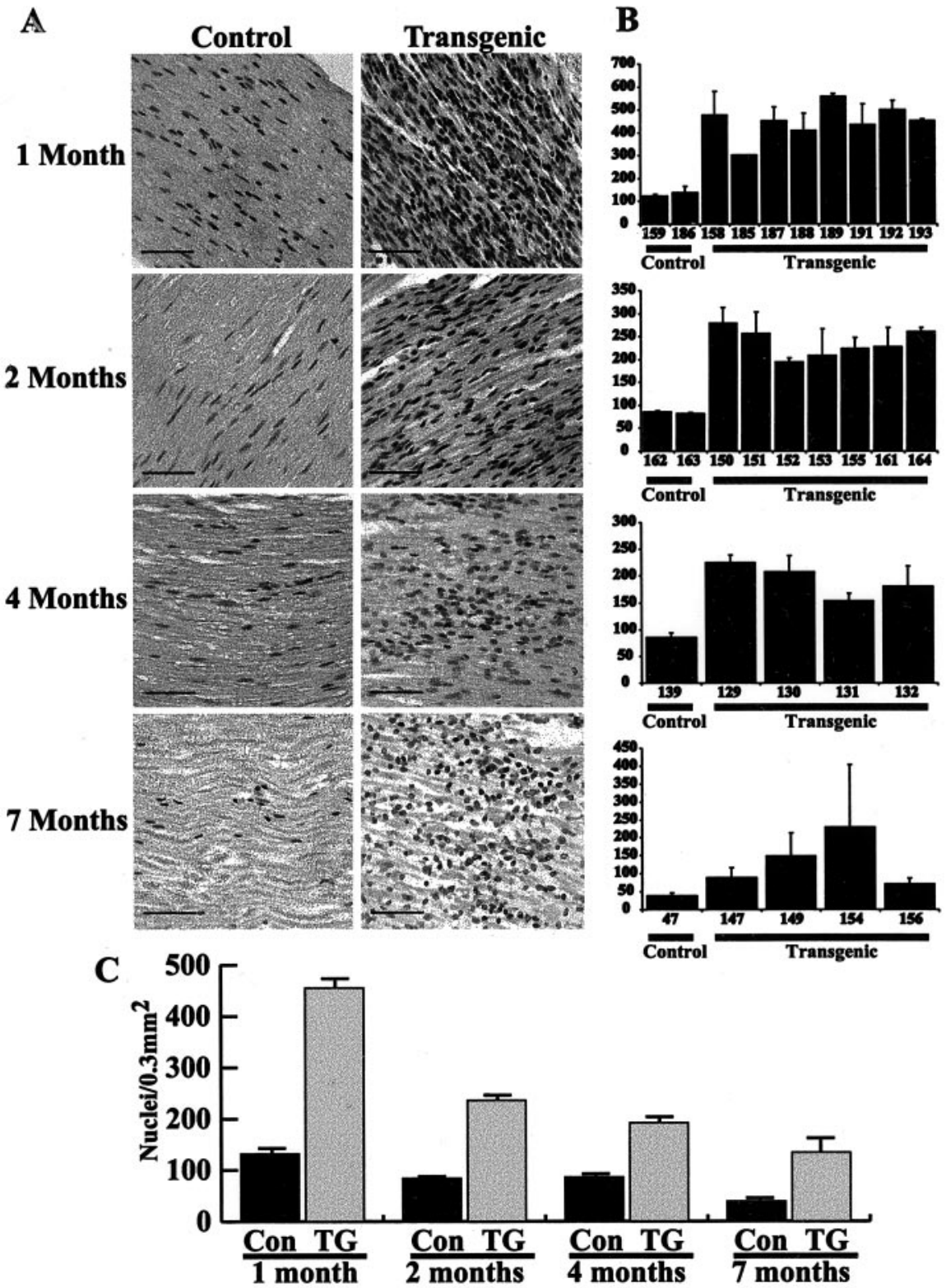

Figure 4. $A$, Representative hematoxylin- and eosin-stained longitudinal sections of sciatic nerve from $P_{0}$-GGF $\beta 3$ transgenic mice (Transgenic) and age-matched nontransgenic controls (Control) at 1, 2, 4, and 7 months of age; ages, indicated to the left of each row, apply both to the images in that row and the adjacent bar graph. Note that sciatic nerves from transgenic animals have higher Schwann cell densities at all ages than seen in age-matched controls. In both transgenic and control mice, however, the number of Schwann cell nuclei per $0.3 \mathrm{~mm}^{2}$ decreases with age. Magnification, $40 \times$; scale bars, $50 \mu \mathrm{m}$. $B$, Bars indicate the average number of Schwann cell nuclei per high-power field at (top to bottom) 1, 2, 4, and 7 months of age in sciatic nerves from $P_{0}$-GGF $\beta 3$ transgenic mice (Transgenic) and age-matched nontransgenic controls (Control). SD is indicated for each bar. Numbers below each bar are animal identifiers. C, Alterations in the average number of Schwann cell nuclei per high-power field $\left(0.3 \mathrm{~mm}^{2}\right)$ with age in $\mathrm{P}_{0}$-GGF $\beta 3$ transgenic mice (TG) and nontransgenic littermates (CON). SEM is indicated for each bar. The age of the animals is indicated below each pair of bars.

MPNSTs (Taxy et al., 1981; Erlandson and Woodruff, 1982; Arpornchayanon et al., 1984; Herrera and Pinto de Moraes, 1984; Erlandson, 1985; Dickersin, 1987; Takeuchi and Ushigome, 2001). Considered together, the histologic, immunohistochemi$\mathrm{cal}$, and ultrastructural features of the neoplasms developing in $\mathrm{P}_{0}$-GGF $\beta 3$ mice meet the World Health Organization criteria (Woodruff et al., 2000) for classification as MPNSTs. Per consensus recommendations (Weiss et al., 2002), these neoplasms are referred to below as genetically engineered murine (GEM) MPNSTs. 

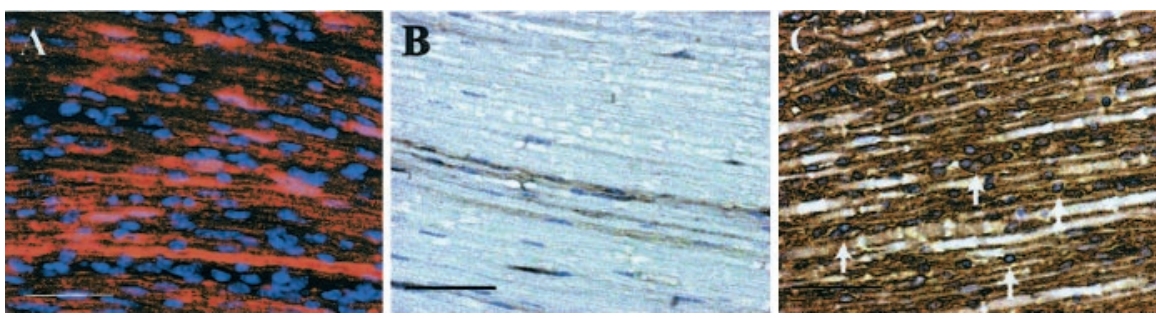

Figure 5. Hyperplastic cells in the sciatic nerves of $\mathrm{P}_{0}-\mathrm{GGF} \beta 3$ mice are associated with $\mathrm{Sch}$ wann cell markers. $A$, Immunoreactivity for the $S c h w a n n$ cell marker $\mathrm{S} 100 \beta$ (red staining) in the sciatic nerve from a 1-month-old $\mathrm{P}_{0}-\mathrm{GGF} \beta 3$ mouse. This preparation has been counterstained with the nuclear marker bisbenzamide to demonstrate the hyperplastic elements. $B, C$, Immunoreactivity for the basal lamina protein collagen type IV is seen as faint brown staining surrounding Schwann cell units in the sciatic nerve from a 1-month-old nontransgenic mouse $(B)$. In contrast, there is prominent collagen type IV deposition in the sciatic nerve from a 1-month-old $P_{0}-G G F \beta 3$ mouse $(C)$, some of which is seen to surround individual hyperplastic cells within this tissue (arrows). In $B$ and $C$, sections have been counterstained with hematoxylin to highlight nuclei within the sections. Magnification, $63 \times$; scale bars, $50 \mu \mathrm{m}$.

If NRG-1 overexpression promotes the continued growth of the GEM MPNSTs developing in $\mathrm{P}_{0}$-GGF $\beta 3$ mice, then expression of the $\mathrm{P}_{0}-\mathrm{GGF} \beta 3$ transgene should be maintained in these neoplasms, and the tumor cells should express the receptors necessary for NRG-1 responsiveness. Examining the expression of the $\mathrm{P}_{0}$-GGF $\beta 3$ transgene using transgene-specific primers, we found that GGF $\beta 3$ mRNA was readily detectable in trigeminalassociated tumor from transgenic mice but not in trigeminal nerve from nontransgenic littermates (Fig. 6G). Furthermore, the NRG-1 receptor subunits erbB2 and erbB3 were expressed in GEM MPNST (Fig. $6 H$ ). A comparison of the levels of erbB2 and erbB3 protein in GEM MPNSTs and trigeminal nerves from 5and 7-month-old $\mathrm{P}_{0}$-GGF $\beta 3$ mice indicated that both erbB kinases were markedly overexpressed in the tumor relative to the levels evident in nerves not containing grossly evident neoplasm; because it was not possible to detect erbB protein in the trigeminal nerve while simultaneously avoiding saturation of the signals from the tumor, we could not accurately quantitate the relative levels of expression in these tissues. Nonetheless, it is apparent that both GGF $\beta 3$ and its erbB receptors are expressed in GEM MPNSTs, suggesting that these molecules promote tumor cell proliferation via autocrine or paracrine effects.

\section{Localized Schwann cell hyperplasia is present in multiple peripheral nervous system ganglia in $\mathrm{P}_{0}$-GGF $\beta 3$ transgenic mice}

The majority of the MPNST-like neoplasms in $\mathrm{P}_{0}$-GGF $\beta 3$ mice are associated with the trigeminal ganglion. This observation suggested that preneoplastic lesions might be specifically associated with this structure in $\mathrm{P}_{0}$-GGF $\beta 3$ mice. To test this hypothesis, we examined trigeminal nerves and associated ganglia from $\mathrm{P}_{0^{-}}$ GGF $\beta 3$ transgenic mice and age-matched wild-type controls at 1, 2,4 , and 7 months of age. As in the sciatic nerve, increased numbers of Schwann cell nuclei were uniformly evident within the trigeminal ganglia of $\mathrm{P}_{0}$-GGF $\beta 3$ animals at all ages examined (Fig. 7). However, unlike the proliferations in sciatic nerve, Schwann cell hyperplasia was predominantly associated with the ganglia, with much less hypercellularity present in adjacent regions of the trigeminal nerve. Furthermore, hypercellular collections of Schwann cells were frequently seen extending from the areas of hyperplasia within the ganglion along the surface of the trigeminal nerve. As in the sciatic nerve, Schwann cell density appeared to decrease with increasing age within the trigeminal ganglion. Because of the nonuniform distribution of Schwann cells within the trigeminal nerve, however, it was not possible to quantitate with accuracy the average Schwann cell density in this structure.

On the basis of these findings, we examined sympathetic (superior cervical, superior mesenteric, and celiac) and sensory (dorsal root) ganglia from $\mathrm{P}_{0}$-GGF $\beta 3$ mice for evidence of similar hyperplastic lesions. We found that Schwann cell hyperplasia was evident in sympathetic ganglia, much as seen in the trigeminal ganglia. Such changes were never seen in sympathetic ganglia from age-matched nontransgenic controls. Schwann cell hyperplasia was also present in dorsal root ganglia (DRG) from transgenic animals; furthermore, in some animals, although there was no evidence of massive tumors arising in the DRG, these structures were grossly enlarged and showed histologic findings similar to those of the MPNST-like neoplasms described above (data not shown). In both the sympathetic and sensory ganglia, Schwann cell hyperplasia was most prominent within the ganglion, with much lower cellularity evident in the adjacent nerve; again, hypercellular collections of Schwann cells were observed extending from the ganglion along the surface of the adjacent nerve. Occasionally, microscopic lesions histologically similar to the tumors identified in this line of $\mathrm{P}_{0}$-GGF $\beta 3$ mice were seen within peripheral ganglia. We conclude that persistent Schwann cell hyperplasia, possibly representing preneoplastic lesions, is uniformly present in motor, sympathetic, and sensory ganglia within the PNS of $\mathrm{P}_{0}$-GGF $\beta 3$ transgenic mice.

\section{Increased Schwann cell DNA synthesis is evident in sciatic nerves and trigeminal ganglia from $\mathrm{P}_{0}$-GGF $\beta 3$ transgenic mice}

The increased number of Schwann cell nuclei evident in the sciatic nerves and trigeminal ganglia of $\mathrm{P}_{0}$-GGF $\beta 3$ mice could reflect increased proliferation, enhanced survival, or a combination of these two factors. To investigate the possibility that the increase in Schwann cell numbers is attributable to increased mitogenesis, 1-, 2-, and 4-month-old transgenic mice and age-matched nontransgenic controls were injected intraperitoneally with $60 \mathrm{mg} / \mathrm{kg}$ BrdU and $6 \mathrm{mg} / \mathrm{kg} 5$-FU (to enhance BrdU incorporation) and killed 90 min later. Sciatic and trigeminal nerves from these animals were fixed, paraffin-embedded, and immunolabeled for incorporated BrdU. Consistent with earlier observations in the sciatic nerves of 2-month-old mice (Asbury, 1967), BrdUimmunoreactive Schwann cell nuclei were rare in sciatic nerves from 1-, 2-, and 4-month-old wild-type mice (Fig. 8A-C). In contrast, multiple BrdU-positive nuclei were seen in sciatic nerve sections from 1-, 2-, and 4-month-old $\mathrm{P}_{0}$-GGF $\beta 3$ mice (Fig. $8 D-F$, arrows). Similar increases in the number of BrdUimmunoreactive Schwann cell nuclei were evident within the trigeminal ganglia of $\mathrm{P}_{0}-\mathrm{GGF} \beta 3$ transgenic mice.

To quantitate these differences, BrdU labeling indices (the number of BrdU-positive Schwann cell nuclei divided by the total number of Schwann cell nuclei) were determined for sciatic nerves and trigeminal ganglia from 1-, 2-, and 4-month-old $\mathrm{P}_{0^{-}}$ GGF $\beta 3$ transgenic mice and age-matched non-transgenic controls. In the sciatic nerve, BrdU labeling indices were significantly higher in $\mathrm{P}_{0}$-GGF $\beta 3$ mice than in wild-type controls at 1 and 2 months of age (Fig. 8G). However, BrdU labeling indices in sciatic nerve from $\mathrm{P}_{0}$-GGF $\beta 3$ mice demonstrated an age-related 
decrease, with an average labeling index of $1.2 \%$ in 1-month-old animals and a $0.2 \%$ labeling index in 4-month-old mice; this decrease occurred despite continued highlevel expression of GGF $\beta 3$ in the sciatic nerve out to 4 months of age (see Fig. $1 B$ ). Likewise, BrdU labeling indices in the trigeminal ganglia of both 1 - and 2-monthold $\mathrm{P}_{0}$-GGF $\beta 3$ mice were much higher than that observed in age-matched wildtype controls (data not shown). We conclude that Schwann cell DNA synthesis is increased in both the sciatic nerve and trigeminal ganglion of mice overexpressing GGF $\beta 3$ in myelinating Schwann cells. It is currently unclear why Schwann cell DNA synthesis decreases with increasing age in $\mathrm{P}_{0}$-GGF $\beta 3$ mice despite continued GGF $\beta 3$ expression.

To assess the possibility that overexpression of GGF $\beta 3$ increases Schwann cell numbers by repressing apoptosis, we stained sciatic and trigeminal nerve sections from 1-, 2-, and 4-month-old $\mathrm{P}_{0^{-}}$ GGF $\beta 3$ transgenic and wild-type mice with an antibody specific for activated caspase-3, the predominant effector caspase in the nervous system. We found only very rare Schwann cells that were immunoreactive for activated caspase-3, showed apoptotic nuclear features, or both in wild-type mice; these findings are consistent with previous studies in which it has been found that developmental Schwann cell apoptosis is essentially complete in rats before postnatal day 21 and that apoptosis is virtually absent in normal sciatic nerve from adult rats (Grinspan et al., 1996). We also found only rare activated caspase-3-immunoreactive Schwann cells in nerve sections from $\mathrm{P}_{0}$-GGF $\beta 3$ transgenic mice. We conclude that the levels of Schwann cell apoptosis in the sciatic and trigeminal nerves of 1-, 2-, and 4-month-old mice are exceedingly low; hence, inhibition of baseline Schwann cell apoptosis likely makes a minimal contribution to the increased cellularity observed in mice overexpressing GGF $\beta 3$ in peripheral nerve.
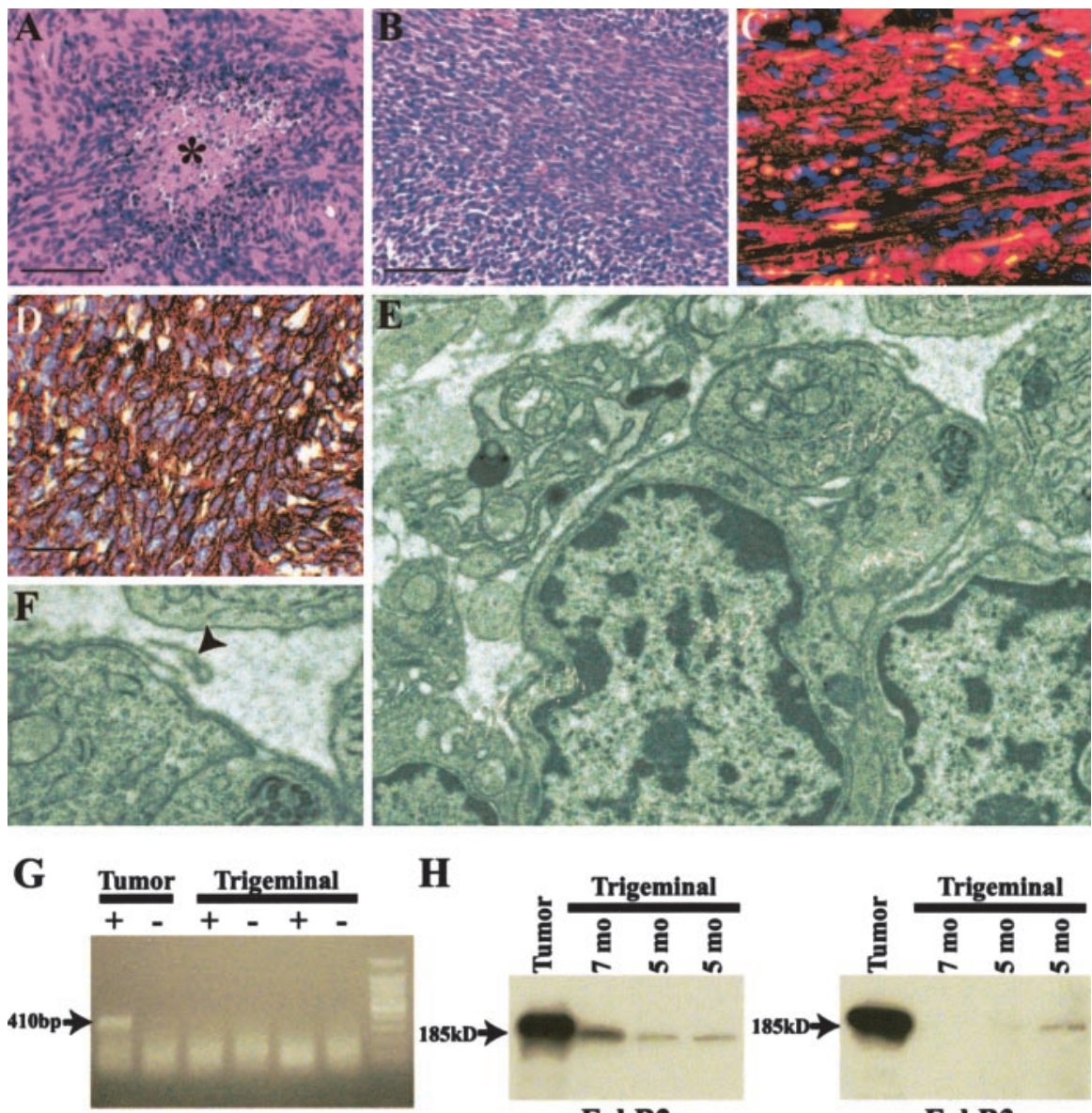

$\mathbf{H}$

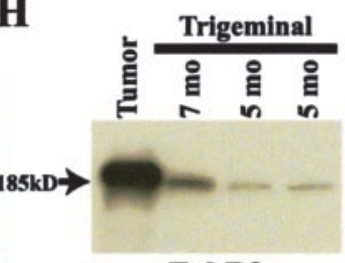

ErbB2

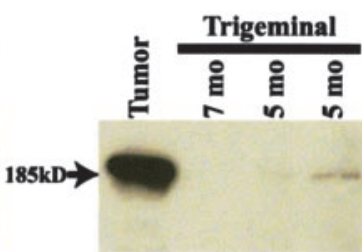

ErbB3
Figure 6. $\quad \mathrm{P}_{0}-\mathrm{GGF} \beta 3$ transgenic mice develop tumors resembling human malignant peripheral nerve sheath tumors. $A, B$, Representative sections of trigeminal ganglion-associated tumors from $\mathrm{P}_{0}-\mathrm{GGF} \beta 3$ founders $34(A)$ and $33(B)$. The asterisk in $A$ indicates a focus of tumor necrosis. Magnification, $40 \times$; scale bar, $50 \mu \mathrm{m}$. C, Section of the neoplasm shown in $B$ immunostained for the Schwann cell marker $S 100 \beta$ (red staining). This preparation has been counterstained with the nuclear marker bisbenzamide. Magnification, $63 \times$; scale bar $20 \mu \mathrm{m}$. D, Section of the neoplasm shown in Bimmunostained for the basement membrane protein collagen type IV. Collagen type IV immunoreactivity is seen as brown staining that invests individual tumor cells. This preparation has been counterstained with hematoxylin to demonstrate individual tumor cells. Magnification, $63 \times$; scale bar, 20 $\mu \mathrm{m} . E, F$, Transmission electron micrographs of a neoplasm developing in an offspring of founder 33 . Note that individual tumor cells are surrounded by a basal lamina (shown at higher magnification in $F$ ), with loops of basal lamina material frequently seen extending away from the tumor cells ( $F$, arrowhead). Magnification: $E, 10,000 \times ; F, 40,000 \times$. G, Expression of the $\mathrm{P}_{0}$-GGF $\beta 3$ transgene is maintained in the MPNST-like tumors developing in $\mathrm{P}_{0}-\mathrm{GGF} \beta 3$ mice. The transgene mRNA is detected as a 410 bp $P C R$ product in CDNA from the tumor shown in $E$ and $F$ (Tumor) but not in CDNAs from age-matched nontransgenic trigeminal nerves (Trigeminal). The transgene product is not detected in the absence of reverse transcription (- lanes), indicating that the $P C R$ product obtained in these experiments is not derived from contaminating genomic DNA. $H$, Tumors from $\mathrm{P}_{0}-\mathrm{GGF} \beta 3$ mice express high levels of the NRG-1 receptor subunits erbB2 and erbB3. ErbB2 (left) and erbB3 (right) are detected as 185 kDa immunoreactive species in lysates of the tumor shown in $E$ and $F$ (Tumor) and in trigeminal nerve (Trigeminal) collected from 5- and 7-monthold $\mathrm{P}_{0}-\mathrm{GGF} \beta 3$ mice.

\section{Discussion}

To determine what effects NRG-1 elicits in mature Schwann cells, we generated transgenic mice constitutively overexpressing the NRG-1 isoform GGF $\beta 3$ in noninjured peripheral nerves. After an initial period of myelination that occurs coincident with prominent Schwann cell hyperplasia, these mice develop a hypertrophic neuropathy, a condition produced by repetitive rounds of demyelination and remyelination. Many $\mathrm{P}_{0}-\mathrm{GGF} \beta 3$ mice also develop ganglion-associated neoplasms similar to human MPNSTs, a tumor type that occurs sporadically or in association with neurofibromatosis type 1 . These MPNST-like neoplasms likely arise from preneoplastic lesions uniformly present in motor, sympathetic, and sensory ganglia from $\mathrm{P}_{0}-\mathrm{GGF} \beta 3$ animals. Considered together, these findings have important implications regarding NRG-1 actions on mature Schwann cells in normal and injured peripheral nerve and the possible involvement of NRG-1 in the pathogenesis of peripheral nerve sheath tumors.

All four $\mathrm{P}_{0}-\mathrm{GGF} \beta 3$ founders and the progeny of founder 33 developed a hypertrophic neuropathy characterized by onion bulb formation with evidence of active demyelination and remyelination. Myelination is relatively normal in 1-month-old $\mathrm{P}_{0^{-}}$ GGF $\beta 3$ mice, with pathology first becoming evident at $\sim 2$ months of age and worsening thereafter. The ability of GGF $\beta 3$ to induce demyelination in the noninjured sciatic nerve of $\mathrm{P}_{0}$ GGF $\beta 3$ transgenic mice is consistent with a previous report that this NRG-1 isoform promotes demyelination in myelinated co- 


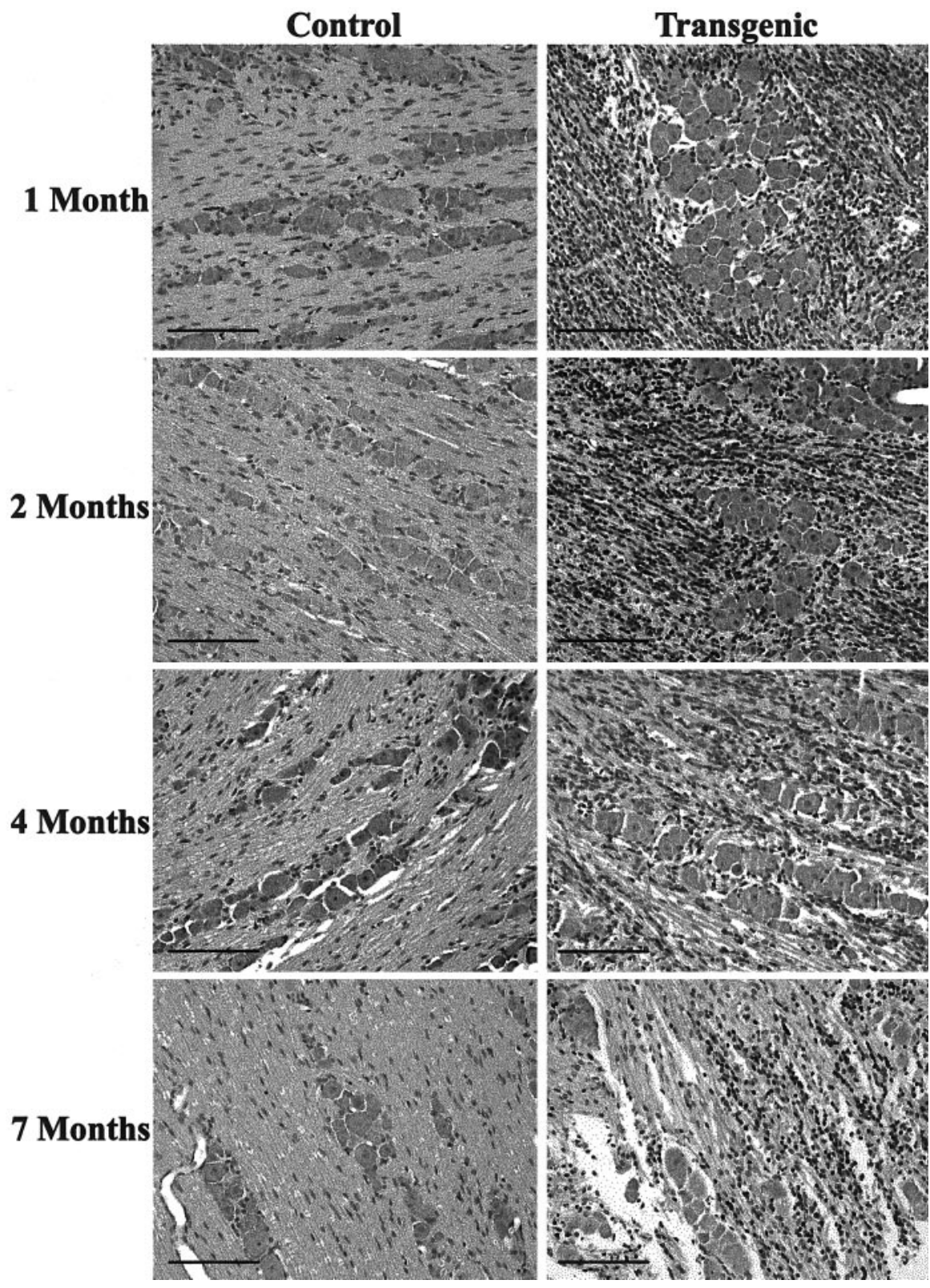

Figure 7. The MPNST-like tumors in $\mathrm{P}_{0}-\mathrm{GGF} \beta 3$ transgenic mice likely arise from preneoplastic lesions uniformly present in peripheral ganglia from these mice. Shown are representative hematoxylin- and eosin-stained sections of the trigeminal ganglia from $\mathrm{P}_{0}-\mathrm{GGF} \beta 3$ transgenic mice (Transgenic) and nontransgenic age-matched controls (Control). The ages of these animals are indicated at the left. Magnification, $20 \times$; scale bars, $100 \mu \mathrm{m}$.

cultures of mature Schwann cells and DRG neurons (Zanazzi et al., 2001). GGF $\beta 3$-mediated repression of myelin protein expression is also consistent with the development of onion bulbs in the sciatic nerves of $\mathrm{P}_{0}$-GGF $\beta 3$ mice; alternative cycles of induction and repression of GGF $\beta 3$ expression, which is controlled in these animals by the regulatory elements of the $\mathrm{P}_{0}$ gene, would be expected to produce the repetitive cycles of demyelination and remyelination that produce these pathologic structures. Thus, both in vivo and in vitro studies demonstrate that GGF $\beta 3$ induces demyelination in differentiated adult Schwann cells. The NRG-1 effects on myelination in this setting are likely distinct from those reported in the neonatal period, in which ablation of the erbB2 locus inhibits the initial establishment of myelination (Garratt et al., 2000b). The occurrence of demyelination in $\mathrm{P}_{0}$-GGF $\beta 3$ mice is thus consistent with the hypothesis that NRG-1 stimulates de- myelination when its expression is induced after injury of the adult nerve.

Sciatic nerve pathology in $\mathrm{P}_{0}$-GGF $\beta 3$ mice is similar to that of human hypertrophic neuropathies such as hereditary sensory and motor neuropathy I (HMSN I; Charcot-Marie-Tooth disease). Nonetheless, it is unlikely that the NRG-1 locus is mutated in HMSN I. Most cases of HMSN I develop as a consequence of mutations in the peripheral myelin protein 22, connexin $32, \mathrm{P}_{0}$, and EGR2 genes (Young and Suter, 2001). Furthermore, although rare forms of HMSN I exist for which the gene locus has not yet been identified, none of the mapping studies performed to date have implicated the NRG-1 locus in the pathogenesis of these neuropathies. These observations do not exclude a role for NRG-1 in the development of HMSN I. Indeed, given the effects this growth factor has on myelination, it is quite possible that NRG-1 plays a role in the pathogenesis of human hypertrophic neuropathies.

In addition to demyelination, we found that GGF $\beta 3$ stimulates in vivo Schwann cell mitogenesis. Sciatic nerves from $\mathrm{P}_{0^{-}}$ GGF $\beta 3$ mice as young as 1 month of age show a marked increase in Schwann cell nuclear density relative to nontransgenic controls. Although average Schwann cell densities decreased with age in both transgenic and nontransgenic mice, Schwann cell numbers in $\mathrm{P}_{0}$-GGF $\beta 3$ mice were significantly higher than in control mice out to 7 months of age. This GGF $\beta 3$-mediated increase in Schwann cell numbers was accompanied by increased bromodeoxyuridine incorporation, indicating that stimulation of Schwann cell proliferation was a major mechanism increasing Schwann cell numbers in $\mathrm{P}_{0}$-GGF $\beta 3$ mice. In contrast, there was little evidence of Schwann cells immunoreactive for activated caspase-3, a major mediator of nervous system programmed cell death, in sciatic nerves from 1-, 2-, and 4-month-old wild-type or transgenic mice. We cannot yet rule out the possibility that transgenic overexpression of GGF $\beta 3$ diminishes the extent of programmed cell death normally occurring during the first postnatal week (Grinspan et al., 1996), thereby contributing to an initial increase in Schwann cell numbers. Nonetheless, our findings in older mice are consistent with the hypothesis that NRG-1 stimulates Schwann cell mitogenesis in injured adult nerve. It is not yet clear whether the promitogenic action of NRG-1 in this setting is distinct from its demyelinative effects.

Constitutive overexpression of GGF $\beta 3$ was also associated with the development of MPNST-like tumors in two $P_{0}-G G F \beta 3$ lines. This finding is consistent with several previous observations linking the NRG-1-erbB signaling pathway to Schwann cell neoplasia. First, Brockes et al. (1986) detected high to intermediate levels of a GGF-like activity in a subset of human neurofibro- 
mas (the precursor lesion from which many MPNSTs arise) and low levels of this activity in the single MPNST they examined. Furthermore, malignant schwannomas (a MPNST variant) induced by in utero treatment of rats (Perantoni et al., 1987; Nikitin et al., 1991), mice (Buzard et al., 1999b), or hamsters (Buzard et al., 1999a) with the mutagen $N$-ethyl-Nnitrosourea (EtNU), frequently carry a form of the NRG-1 receptor subunit erbB2 with an activating point mutation. Last, we have found that JS1 cells (Schubert et al., 1974; Kimura et al., 1990), a Schwann cell line derived from an EtNU-induced MPNST, express high levels of several NRG-1 isoforms (including GGF variants), erbB3, and a nonmutated form of erbB2 (Frohnert et al., 2003). JS1 cells demonstrate constitutive tyrosine phosphorylation of these erbB kinases, which can be blocked pharmacologically, resulting in a marked decrease in DNA synthesis. These observations, considered together with our finding that overexpression of GGF $\beta 3$ induces MPNST formation, are consistent with the hypothesis that constitutive activation of the NRG-1-erbB signaling pathway induces Schwann cell neoplasia in rodents. The role of these signaling events in the pathogenesis of human Schwann cell neoplasms remains to be determined.

Although GGF $\beta 3$ overexpression contributes to the development of MPNSTlike tumors in $\mathrm{P}_{0}$-GGF $\beta 3$ mice, it is unlikely that this is the only molecular event involved in this process. Several factors support this conclusion, including the nonuniform development of these neoplasms in the PNS (see below), the occurrence of MPNSTs in only some animals, and the tendency of these tumors to be found in older animals. At present, it is unclear whether these additional genetic events include those previously identified in human MPNSTs such as inactivation of the NF1 (Perry et al., 2001), Rb (Birindelli et al., 2001), p53 (Menon et al., 1990; Birindelli et al., 2001), and CDKN2A/p16 (Kourea et al., 1999; Nielsen et al., 1999) genes. These additional mutations likely occur in cells within the hyperplastic lesions uniformly present in the motor, sensory, and sympathetic peripheral ganglia of $\mathrm{P}_{0}$-GGF $\beta 3$ mice. Several features suggest that the hyperplastic lesions in ganglia are preneoplastic, including their relatively high degree of cellularity, their association with the ganglion (see below), and the tendency of cells in these regions to extend outward along the epineurium.

In humans, MPNSTs are most frequently found in large nerves such as the sciatic nerve. However, human MPNSTs also develop in cranial nerves, most commonly in the trigeminal ganglion or its peripheral branches (Urich and Tien, 1998). Like this minor subset of human MPNSTs, the majority of the MPNSTs developing in $\mathrm{P}_{0}$-GGF $\beta 3$ mice arose within trigeminal ganglia. A similar distribution is seen for MPNSTs induced in rats and mice by in utero carcinogenesis with EtNU (Druckrey et al., 1966;
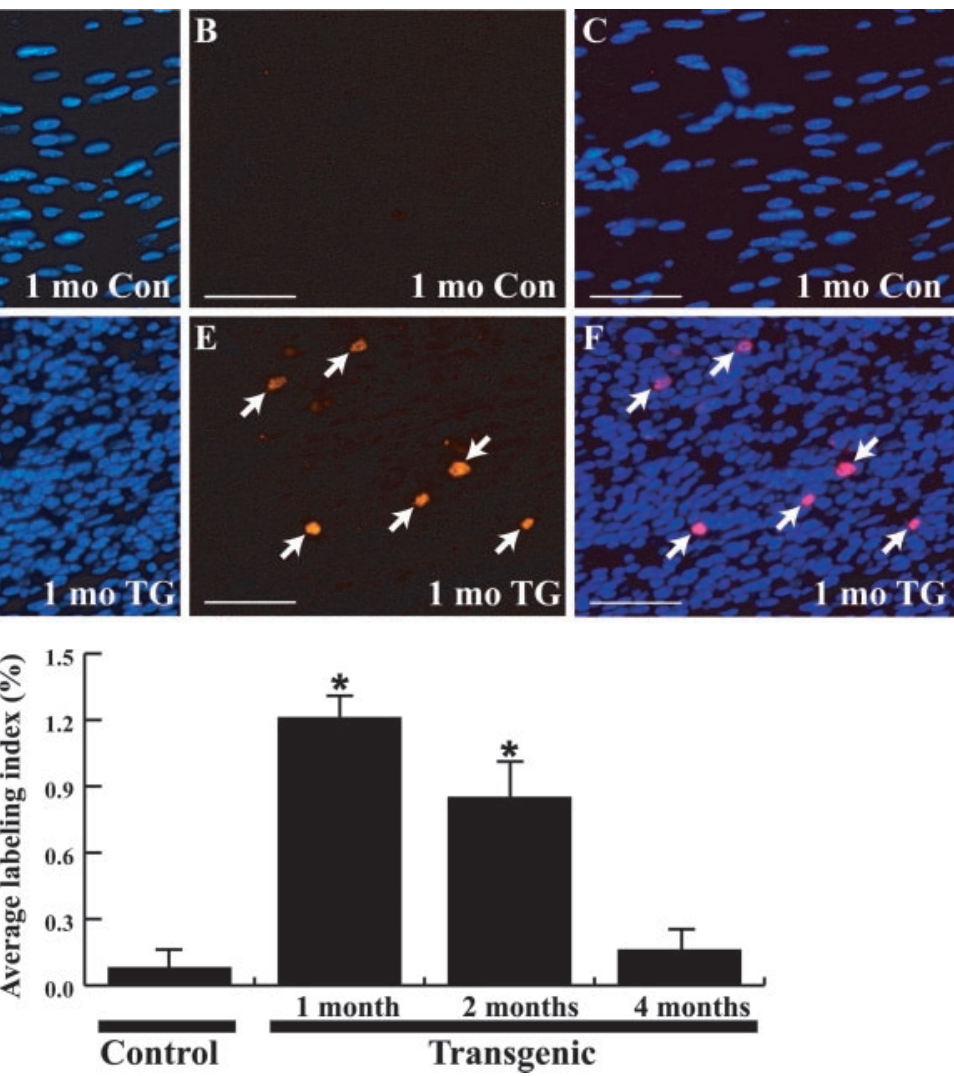

Figure 8. DNA synthesis in sciatic nerves from $\mathrm{P}_{0}-\mathrm{GGF} \beta 3$ transgenic and wild-type mice. $A-C$, Representative section from a 1-month-old wild-type control (1 mo Con) mouse. $D-F$, Representative section from a 1-month-old $\mathrm{P}_{0}$-GGF $\beta 3$ transgenic (1 mo ) mouse. Left column, Staining for the nuclear dye bisbenzamide. Middle column, Immunostaining for incorporated BrdU. Righ wild-type controls were compared using one-way ANOVA, followed by Tukey's post hoc test, with $p<0.05$ considered statistically significant. ${ }^{*} p \ll 0.001$ relative to nontransgenic controls.

Wechsler et al., 1979; Anderson et al., 1989; Buzard et al., 1999b). The preferential association of EtNU-induced tumors with the trigeminal ganglion has been suggested to reflect the developmental state of this structure at embryonic day 15, the time of EtNU exposure (Nikitin et al., 1991). However, because NRG-1 overexpression in $\mathrm{P}_{0}$-GGF $\beta 3$ mice likely occurs with a different time course from EtNU exposure, other possibilities must be considered. First, PNS ganglia may contain a distinct Schwann cell subtype particularly sensitive to NRG-1 stimulation. Second, MPNSTs and their precursor lesions may arise from some other NRG-responsive glial lineage specific to ganglia such as satellite cells; alternatively, MPNSTs may develop from immature Schwann cell-like elements or stem cells analogous to those recently identified in the adult gut (Kruger et al., 2002) that are persistently present in perinatal or adult ganglia. Last, other factors unique to the ganglionic microenvironment (e.g., costimulation by growth factors released from ganglionic neurons) may alter Schwann cell responses to NRG-1 stimulation.

In conclusion, overexpression of GGF $\beta 3$ in noninjured peripheral nerves induces Schwann cell proliferation and demyelination, ultimately resulting in the development of both a hypertrophic neuropathy similar to Charcot-Marie-Tooth disease and 
neoplasms resembling the human malignant peripheral nerve sheath tumors that occur both sporadically and in association with neurofibromatosis type 1 . The effects produced by GGF $\beta 3$ overexpression are therefore consistent with the hypothesis that NRG-1 isoforms mediate both demyelination and Schwann cell proliferation after injury of an adult peripheral nerve. Given its phenotype, the $\mathrm{P}_{0}$-GGF $\beta 3$ transgenic mouse will be highly useful in future studies further examining NRG-1 actions on nontransformed mature Schwann cells in vivo and the role NRG-1 plays in Schwann cell neoplasia.

\section{References}

Adlkofer K, Lai C (2000) Role of neuregulins in glial cell development. Glia 29:104-111.

Anderson LM, Hagiwara A, Kovatch RM, Rehm S, Rice JM (1989) Transplacental initiation of liver, lung, neurogenic and connective tissue tumors by $N$-nitroso compounds in mice. Fund Appl Toxicol 12:604-620.

Arpornchayanon O, Hirota T, Itabashi M, Nakajima T, Fukuma H, Beppu Y, Nishikawa K (1984) Malignant peripheral nerve tumors: a clinicopathological and electron microscopic study. Jpn J Clin Oncol 14:57-74.

Asbury AK (1967) Schwann cell proliferation in developing mouse sciatic nerve: a radioautographic study. J Cell Biol 34:735-743.

Baron-Van Evercooren A, Gansmuller A, Gumpel M, Baumann N, Kleinman HK (1986) Schwann cell differentiation in vitro: extracellular matrix deposition and interaction. Dev Neurosci 8:182-196.

Bermingham-McDonogh O, Xu Y-T, Marchionni MA, Scherer SS (1997) Neuregulin expression in PNS neurons: isoforms and regulation by target interactions. Mol Cell Neurosci 10:184-195.

Birindelli S, Perrone F, Oggionni M, Lavarino C, Pasini B, Vergani B, Ranzani GN, Pierotti MA, Pilotti S (2001) Rb and TP53 pathway alterations in sporadic and NF1-related malignant peripheral nerve sheath tumors. Lab Invest 81:833-844.

Brockes JP, Breakefield XO, Martuza RL (1986) Glial growth factor-like activity in Schwann cell tumors. Ann Neurol 20:317-322.

Buzard GS, Enomoto T, Hongyo T, Perantoni AO, Diwan BA, Devor DE, Reed CD, Dove LF, Rice JM (1999a) neu mutation in schwannomas induced transplacentally in Syrian golden hamsters by $\mathrm{N}$-nitrosoethylurea: high incidence but low allelic representation. J Cancer Res Clin Oncol 125:529-540.

Buzard GS, Enomoto T, Anderson LM, Perantoni AO, Devor DE, Rice JM (1999b) Activation of neu by missense point mutation in the transmembrane domain in schwannomas induced in $\mathrm{C} 3 \mathrm{H} / \mathrm{HeNCr}$ mice by transplacental exposure to $\mathrm{N}$-nitrosoethylurea. J Cancer Res Clin Oncol 125:653-659.

Carroll SL, Frohnert PW (1998) Expression of JE (monocyte chemoattractant protein-1) is induced by sciatic axotomy in wild type rodents but not in C57BL/Wld ${ }^{\text {s }}$ mice. J Neuropathol Exp Neurol 57:915-929.

Carroll SL, Miller ML, Frohnert PW, Kim SS, Corbett JA (1997) Expression of neuregulins and their putative receptors, ErbB2 and ErbB3, is induced during Wallerian degeneration. J Neurosci 17:1642-1659.

Chen MS, Bermingham-McDonogh O, Danehy Jr FT, Nolan C, Scherer SS, Lucas J, Gwynne D, Marchionni MA (1994) Expression of multiple neuregulin transcripts in postnatal rat brains. J Comp Neurol 349:389-400.

Cheng L, Mudge AW (1996) Cultured Schwann cells constitutively express the myelin protein $\mathrm{P}_{0}$. Neuron 16:309-319.

Cheng L, Esch FS, Marchionni MA, Mudge AW (1998) Control of Schwann cell survival and proliferation: autocrine factors and neuregulins. Mol Cell Biol 12:141-156.

Danielson PE, Forss-Petter S, Brow MAD, Calavetta L, Douglass J, Milner RJ, Sutcliffe JG (1988) p1B15: a cDNA clone of the rat mRNA encoding cyclophilin. DNA 7:261-267.

Dickersin GR (1987) The electron microscopic spectrum of nerve sheath tumors. Ultrastruct Pathol 11:103-146.

Dong Z, Brennan A, Liu N, Yarden Y, Lefkowitz G, Mirsky R, Jessen KR (1995) Neu differentiation factor is a neuron-glia signal and regulates survival, proliferation and maturation of rat Schwann cell precursors. Neuron 15:585-596.

Druckrey H, Ivankovic S, Preussmann R (1966) Teratogenic and carcinogenic effects in the offspring after single injection of ethylnitrosourea to pregnant rats. Nature 210:1378-1379.
Erlandson RA (1985) Peripheral nerve sheath tumors. Ultrastruct Pathol 9:113-122.

Erlandson RA, Woodruff JM (1982) Peripheral nerve sheath tumors: an electron microscopic study of 43 cases. Cancer 49:273-287.

Feltri ML, D'Antonio M, Quattrini A, Numerato R, Arona M, Previtali S, Chiu C-Y, Messing A, Wrabetz L (1999) A novel $P_{0}$ glycoprotein transgene activates expression of lacZ in myelin-forming Schwann cells. Eur J Neurosci 11:1577-1586.

Felts PA (1999) Neuregulins in Schwann cell development. Neuroscientist 5:8-11.

Fischbach GD, Rosen KM (1997) ARIA: a neuromuscular junction neuregulin. Annu Rev Neurosci 20:429-458.

Frohnert PW, Stonecypher MS, Carroll SL (2003) Constitutive activation of the neuregulin-1/erbB receptor signaling pathway is essential for the proliferation of a neoplastic Schwann cell line. Glia 43:104-118.

Garratt AN, Britsch S, Birchmeier C (2000a) Neuregulin, a factor with many functions in the life of a Schwann cell. Bioessays 22:987-996.

Garratt AN, Voiculescu O, Topilko P, Charnay P, Birchmeier C (2000b) A dual role of erbB2 in myelination and in expansion of the Schwann cell precursor pool. J Cell Biol 148:1035-1046.

Goodearl ADJ, Davis JB, Mistry K, Minghetti L, Otsu M, Waterfield MD, Stroobant P (1993) Purification of multiple forms of glial growth factor. J Biol Chem 268:18095-18102.

Grinspan JB, Marchionni MA, Reeves M, Coulaloglou M, Scherer SS (1996) Axonal interactions regulate Schwann cell apoptosis in developing peripheral nerve: neuregulin receptors and the role of neuregulins. J Neurosci 16:6107-6118.

Gutmann DH (2001) The neurofibromatoses: when less is more. Hum Mol Genet 10:747-755.

Gutmann DH, Aylsworth A, Carey JC, Korf B, Marks J, Pyeritz RE, Rubenstein A, Viskochil D (1997) The diagnostic evaluation and multidisciplinary management of neurofibromatosis 1 and neurofibromatosis 2 . JAMA 278:51-57.

Herrera GA, Pinto de Moraes H (1984) Neurogenic sarcomas in patients with neurofibromatosis (von Recklinghausen's disease): light, electron microscopy and immunohistochemistry study. Virchows Arch 403:361-376.

Kimura H, Fischer WH, Schubert D (1990) Structure, expression and function of a schwannoma-derived growth factor. Nature 348:257-260.

Kourea HP, Orlow I, Scheithauer BW, Cordon-Cardo C, Woodruff JM (1999) Deletions of the INK4A gene occur in malignant peripheral nerve sheath tumors but not in neurofibromas. Am J Pathol 155:1855-1860.

Kruger GM, Mosher JT, Bixby S, Joseph N, Iwashita T, Morrison SJ (2002) Neural crest stem cells persist in the adult gut but undergo changes in self-renewal, neuronal subtype potential, and factor responsiveness. Neuron 35:657-669.

Kwon YK, Bhattacharyya A, Alberta JA, Giannobile WV, Cheon K, Stiles CD, Pomeroy SL (1997) Activation of erbB2 during Wallerian degeneration of sciatic nerve. J Neurosci 17:8293-8299.

Leong ASY, Vinyuvat S, Suthipintawong C, Leong FJ (1997) Patterns of basal lamina immunostaining in soft-tissue and bony tumors. Appl Immunohistochem Mol Morphol 5:1-7.

Lorimier P, Mezin P, Labat Moleur F, Pinel N, Peyrol S, Stoebner P (1992) Ultrastructural localization of the major components of the extracellular matrix in normal rat nerve. J Histochem Cytochem 40:859-868.

Marchionni MA, Goodearl ADJ, Chen MS, Bermingham-McDonogh O, Kirk C, Hendricks M, Danehy F, Misumi D, Sudhalter J, Kobayashi K, Wroblewski D, Lynch C, Baldassare M, Hiles I, Davis JB, Hsuan JJ, Totty NF, Otsu M, McBurney RN, Waterfield MD, Stroobant P, Gwynne D (1993) Glial growth factors are alternatively spliced erbB2 ligands expressed in the nervous system. Nature 362:312-318.

Menon AG, Anderson KM, Riccardi VM, Chung RY, Whaley JM, Yandell DW, Farmer GE, Freiman RN, Lee JK, Li FP, Barker DF, Ledbetter DH, Kleider A, Martuza RL, Gusella JF, Seizinger BR (1990) Chromosome $17 p$ deletions and $p 53$ gene mutations associated with the formation of malignant neurofibrosarcomas in von Recklinghausen neurofibromatosis. Proc Natl Acad Sci USA 87:5435-5439.

Meyer D, Yamaai T, Garratt A, Riethmacher-Sonnenberg E, Kane D, Theill LE, Birchmeier C (1997) Isoform-specific expression and function of neuregulin. Development 124:3575-3586.

Morris JK, Lin W, Hauser C, Marchuk Y, Getman D, Lee K-F (1999) Rescue 
of the cardiac defect in erbB2 mutant mice reveals essential roles of erbB2 in peripheral nervous system development. Neuron 23:273-283.

Nielsen GP, Stemmer-Rachamimov AO, Ino Y, Moller MB, Rosenberg AE, Louis DN (1999) Malignant transformation of neurofibromas in neurofibromatosis 1 is associated with CDKN2A/p16 inactivation. Am J Pathol 155:1879-1884.

Nikitin AY, Ballering LAP, Lyons J, Rajewsky MF (1991) Early mutation of the neu (erbB-2) gene during ethylnitrosourea-induced oncogenesis in the rat Schwann cell lineage. Proc Natl Acad Sci USA 88:9939-9943.

Parada LF (2000) Neurofibromatosis type 1. Biochim Biophys Acta 1471:M13-M19.

Perantoni AO, Rice JM, Reed CD, Watatani M, Wenk ML (1987) Activated neu oncogene sequences in primary tumors of the peripheral nervous system induced in rats by transplacental exposure to ethylnitrosourea. Proc Natl Acad Sci USA 84:6317-6321.

Perry A, Roth KA, Banerjee R, Fuller CE, Gutmann DH (2001) NF1 deletions in S-100 protein-positive and negative cells of sporadic and neurofibromatosis 1 (NF1)-associated plexiform neurofibromas and malignant peripheral nerve sheath tumors. Am J Pathol 159:57-61.

Schubert D, Heinemann S, Carlisle W, Tarikas H, Kimes B, Patrick J, Steinbach JH, Culp W, Brandt BL (1974) Clonal cell lines from the rat central nervous system. Nature 249:224-227.

Shah NM, Marchionni MA, Isaacs I, Stroobant P, Anderson DJ (1994) Glial growth factor restricts mammalian neural crest stem cells to a glial fate. Cell 77:349-360.

Takeuchi A, Ushigome S (2001) Diverse differentiation in malignant peripheral nerve sheath tumours associated with neurofibromatosis-1: an immunohistochemical and ultrastructural study. Histopathology 39:298-309.

Taxy JB, Battifora H, Trujillo Y, Dorfman HD (1981) Electron microscopy in the diagnosis of malignant schwannoma. Cancer 48:1381-1391.

Topilko P, Murphy P, Charnay P (1996) Embryonic development of
Schwann cells: multiple roles for neuregulins along the pathway. Mol Cell Neurosci 8:71-75.

Urich H, Tien RD (1998) Tumors of the cranial, spinal and peripheral nerve sheaths. In: Russell and Rubinstein's pathology of tumors of the nervous system (Bigner DD, McLendon RE, Bruner JM, eds), pp 141-193. New York: Oxford UP.

Vang R, Biddle DA, Harrison WR, Heck K, Cooley LD (2000) Malignant peripheral nerve sheath tumor with at $(\mathrm{X} ; 18)$ : a synovial sarcoma variant? Arch Pathol Lab Med 124:864-867.

Wechsler W, Rice JM, Vesselinovitch SD (1979) Transplacental and neonatal induction of neurogenic tumors in mice: comparison with related species and with human pediatric neoplasms. Natl Cancer Inst Monogr 51:219-226.

Weiss WA, Israel M, Cobbs C, Holland E, James CD, Louis DN, Marks C, McClatchey AI, Roberts T, Van Dyke T, Wetmore C, Chiu I-M, Giovannini M, Guha A, Higgins RJ, Marino S, Radovanovic I, Reilly K, Aldape K (2002) Neuropathology of genetically engineered mice: consensus report and recommendations from an international forum. Oncogene 21:7453-7463.

Wolpowitz D, Mason TBA, Dietrich P, Mendelsohn M, Talmage DA, Role LW (2000) Cysteine-rich domain isoforms of the Neuregulin-1 gene are required for maintenance of peripheral synapses. Neuron 25:79-91.

Woodruff JM, Kourea HP, Louis DN, Scheithauer BW (2000) Malignant peripheral nerve sheath tumour (MPNST). In: Pathology and genetics of tumours of the nervous system (Kleihues P, Cavenee WK, eds), pp 172174. Lyon, France: International Agency for Research on Cancer.

Young P, Suter U (2001) Disease mechanisms and potential therapeutic strategies in Charcot-Marie-Tooth disease. Brain Res Rev 36:213-221.

Zanazzi G, Einheber S, Westreich R, Hannocks M-J, Bedell-Hogan D, Marchionni M, Salzer JL (2001) Glial growth factor/neuregulin inhibits Schwann cell myelination and induces demyelination. J Cell Biol 152: 1289-1299. 